\title{
Factors Affecting the Decision to Purchase Arabica Coffee via Online (A Case Study of Online Consumers in Blitar Regency)
}

\section{Faktor - Faktor Yang Mempengaruhi Keputusan Pembeliaan Kopi Arabika Secara Online (Studi Kasus Konsumen Online Di Kabupaten Blitar)}

\author{
Widya Ningsih, Yuhanin Zamrodah, Rima Dewi* \\ \{widya9828widy@gmail.com, yuhaninzamrodah@yahoo.com, dewisativa87@gmail.com*\} \\ Program Studi Agribisnis, Fakultas Pertanian, Universitas Islam Balitar, Blitar, Indonesia
}

\begin{abstract}
This study aims to determine the characteristics of Arabica coffee consumers who make online transactions and to see how much influence the given factor has on the decision to purchase Arabica coffee online in Blitar Regency. The execution of this exploration action will be carried out in February 2021 - June 2021 in Blitar Regency. The information-checking strategy used in this exploration is a special examination and various direct examinations of recurrence. Autonomous factor in this research include psychological, personal, social, and cultural. Meanwhile, the dependent variable in this study is the decision to purchase Arabica coffee at online retailers. The results of data analysis found that the X1 (psychological factor) variable was 0.180, X2 (personal factor) was 0.157, X3 (social factor) was 1.012, and X4 (cultural factor) was 0.121 indicating that all variables have positive values. The results of the t-test show that social factors partially influence the purchase decision of Arabica coffee with the online method as shown by the results of $t$ count $>t$ table, namely $5.721>2.059$. And the $F$ test shows that the decision to purchase Arabica coffee online can be influenced simultaneously by psychological, personal, social, and cultural factors with the calculated $F$ result that is $57.781>F$ table which is 2.98 .
\end{abstract}

Keywords - arabica coffee; cultural; online purchasing decisions; online shopping; personal; psychology; social

Abstrak. Penelitian ini bertujuan untuk mengetahui karakteristik konsumen kopi arabika yang melakukan transaksi online dan untuk melihat seberapa besar pengaruh faktor yang diberikan terhadap keputusan pembelian kopi arabika secara online di Kabupaten Blitar. Pelaksanaan kegiatan penelitian ini akan dilaksanakan pada bulan Februari 2021 - Juni 2021 di Kabupaten Blitar. Metode analisa data yang dimanfaatkan pada riset ini adalah analisa deskriptif dan analisia regresi linier berganda. Variabel independen dalam riset ini antara lain psikologi, pribadi, sosial, dan budaya. Sedangkan vriabel terikan dalam penelitian ini adalah keputusan pembelian kopi arabika di ritel online. Hasil analisa data ditemukan bahwa variabel X1(faktor psikologi) sebesar 0,180, X2 (faktor pribadi) sebesar 0,157, X3 (faktor sosial) sebesar 1,012, dan X4 (faktor budaya) sebesar 0,121 menunjukan bahwa seluruh variabel memiliki nilai positif. Hasil uji t menunjukan faktor sosial secara parsial mempengaruhi keputusan pembelian kopi arabika dengan metode online ditunjukan dengan hasil t hitung >t tabel yaitu 5,721 > 2,059. Serta uji $F$ menunjukan bahwa keputusan pembelian kopi arabika secara online dapat dipengaruhi secara simultan oleh faktor psikologi, pribadi, sosial, dan budaya dengan hasil F hitung yaitu 57,781 > F tabel yaitu 2,98.

Kata Kunci - kopi arabika; budaya; keputusan pembelian online; belanja online; pribadi; psikologi; sosial

\section{PENDAHULUAN}

\section{A. Latar belakang}

Indonesia termasuk negara berkembang sekaligus negara agraris dengan kepemilikan hasil alam yang melimpah. Kopi termasuk produk pertanian unggulan dan berpotensi pada subsektor perkebunan yang dibudidayakan di Indonesia. Hal ini dikarenakan kopi berdaya saing tinggi baik di pasar dalam negeri maupun luar negeri.

Kopi termasuk komoditas perkebunan negara Indonesia karena memiliki kontribusi nyata dalam segi perekonomian[6]. Indonesia menjadi produsen kopi terbesar keempat di dunia setelah Brazil, Vietnam, dan Colombia[9].

Pernyataan di atas diperkuat dengan data dari Kementrian Pertanian Republik Indonesia yang menyatakan, produksi kopi di Indonesia khusunya Jawa Timur pada tahun 2016 sebesar 63.568 ton dan mengalami perkembangan produksi sebesar 1.143 ton ditahun 2017 sehingga mencapai 64.711 ton, akan tetapi pada tahun 2018 mengalami penurunan sebanyak 182 ton menjadi 64.529 ton. Namun ditahun 2019 hingga 2020 volume produksi kopi kembali meningkat lagi menjadi 66.681 ton ditahun 2019 dan ditahun 2020 produksi meningkat lagi menjadi 68.769 ton [10].

Akan tetapi terdapat kendala dalam pemasarannya yaitu banyak petani yang belum paham betul cara pemasaran yang jangkauannya luas atau secara online sehingga mengharuskan petani menjual hasil panennya ke tengkulak dengan harga dibawah pasaran. Hal tersebutlah yang membuat para petani kopi merugi, ditambah lagi pada tahun 2020 ini terjadi fenomena dengan adanya virus corona yang menyebabkan perekonomian disegala sektor menurun 
bahkan hancur karena segala aktivitas transaksi berhenti sementara pasar - pasar ditutup dan tempat perbelanjaan serta tempat berkumpul seperti kedai kopi juga ditutup[2].

Transaksi online saat ini semakin meningkat dengan seiring mewabahnya virus Corona di dunia termasuk Indonesia dan daerah Blitar khususnya yang mengharuskan semua orang membatasi kegiatannya di luar rumah[5]. Karena dengan melakukan transaksi secara online dapat meminimalisir kontak langsung dengan orang baru dan orang banyak yang belum diketahui riwayat kesehatan sebelumnya. Masyarakat yang awalnya memilih datang langsung ke pusat perbelanjaan baik yang tradisional ataupun modern. Namun saat ini mulai meninggalkan cara sebelumnya dengan cara berbelanja yang baru yaitu mempercayai foto produk yang ditampilkan dan disertai dengan review atau spesifikasi produk yang dituliskan sebagai caption atau keterangan ditambah dengan menunjukan testimoni dari konsumen sebelumnya oleh ritel online, dan selanjutnya produsen akan memilih produk sesuai kebutuhannya kemudian membeli dan melakukan pembayaran, lalu proses selanjutnya kurir atau jasa pengiriman akan mendatangi rumah konsumen untuk mengantar produk[3].Adanya perubahan tempat pembelian secara daring atau online terhadap produk agribisnis kopi saat ini dipengaruhi beberapa faktor, antara lain tren minum kopi yang sangat populer beberapa tahun ini dan banyaknya jenis kopi yang ada sehingga membuat masyarakat penasaran ingin mencoba kopi dari berbagai daerah yang mengharuskan para penikmat kopi ini melakukan pembelian secara online. Terlebih lagi di Blitar memiliki jenis kopi yang sangat digemari masyarakat yaitu kopi Arabika.

\section{B. Rumusan masalah}

1. Bagaimana karakteristik konsumen kopi Arabika di Kabupaten Blitar?

2. Faktor apa saja yang mempengaruhi konsumen dalam memutuskan pembelian kopi Arabika di Kabupaten Blitar?

\section{Tujuan penelitian}

1. Mengidentifikasi karakteristik konsumen kopi Arabika di Kabupaten Blitar

2. Menganalisis faktor apa saja yang berpengaruh terhadap keputusan konsumsi kopi Arabika secara online di Kabupaten Blitar.

\section{METODE PENELITIAN}

\section{Tempat dan waktu penelitian}

Tempat pelaksanaan kegiatan penelitian di Kabupaten Blitar yang akan dilaksanakan pada bulan Februari 2021 Juni 2021.

\section{E. Metode penentuan sampel}

Penjaminan contoh dalam tinjauan ini dilakukan dengan sengaja, yaitu dengan mengambil contoh menggunakan strategi pemeriksaan non-probabilistik dengan teknik pemeriksaan yang disengaja atau pengujian yang ditargetkan yang sering disebut dependen pada model tertentu [7]. Pembenaran di balik pemilihan contoh menggunakan metode pemeriksaan kesimpulan menyiratkan bahwa tidak semua contoh memiliki pengukuran yang terkoordinasi menggunakan apa yang masih di udara, sehingga pencipta memilih strategi pemeriksaan yang ditetapkan dengan perenungan dan standar luar biasa yang harus puas dengan contoh yang digunakan dalam hal ini. tinjauan. Contoh soal ujian ini terdiri dari 30 contoh, yang dianggap mampu menjawab responden dalam eksplorasi ini.

\section{F. Metode pengumpulan data}

Metode pengumpulan data yang digunakan dalam penelitian ini antara lain menggunakan data primer dan data skunder. Beberapa metode pengumpulan data yang akan digunakan penulis dalam penelitian ini antara lain :

Angket (kuesioner) secara online

Kuesioner yang digunakan oleh penulis dalam penelitian ini mengguanakan kuesioner online dimana penulis memanfaatkan google form sebagai alat dari kuesioner yang dibuat dengan alasan cakupannya lebih luas, lebih menghemat waktu dan biaya dalam penyebaran kuesioner.

\section{Pengumpulan Data Primer}

- Observasi

Teknik observasi dilakukan dengan mengadakan pengamatan langsung terhadap obyek yang akan diteliti sehingga didapatkan gambaran yang jelas mengenai obyek yang akan diteliti.

- Wawancara

Untuk mendapatkan informasi lebih banyak mengenai tanaman kopi beserta hal - hal yang berkaitan dengan kopi salah satunya tentang varietas kopi arabika, teknik dan proses pemasaran kopi Arabika dan sebagainya, dengan melakukan wawancara kepada pengelola kebun kopi.

- Pencatatan 
Procedia of Engineering and Life Science Vol. 2. No. 1 October 2021

Seminar Nasional \& Call Paper Fakultas Sains dan Teknologi (SENASAINS 3rd)

Universitas Muhammadiyah Sidoarjo

Teknik pencatatan dimanfaatkan mengumpulkan data primer dan data sekunder untuk mendukung keakuratan informasi yang diperlukan. Dokumentasi

Pengumpulan Data Skunder

- $\quad$ Studi Pustaka

Pengumpulan data dengan pemanfaatan data yang berasal dari internet atau sumber-sumber literatur yang lain, yang berkaitan dengan kegiatan penelitian skripsi.

\section{G. Metode analisis data}

Strategi investigasi informasi yang dilakukan oleh para ilmuwan dalam eksplorasi ini adalah: pemeriksaan iluminasi dan berbagai kejatuhan, yang dijelaskan sebagai berikut:

Analisis deskriptif

Metode deskriptif merupakan suatu metode yang sering digunakan dalam meneliti mendekripsikan akibat data modern yg diperoleh peneliti. Tujuan penelitian deskriptif ialah untuk menghasilkan deskripsi.

\section{Analisis regresi linier berganda}

Dalam review ini, penulis menggunakan teknik inkuiri informasi dengan menggunakan berbagai direct fallout. Banyak kekambuhan langsung dimaksudkan untuk menguji pengaruh setidaknya 2 faktor bebas (logis) pada variabel dependen, model ini memprediksi garis lurus atau hubungan lurus antara variabel dependen dan masing-masing indikator [1].

Mengikuti garis-garis ini, untuk mengetahui variabel mana yang mempengaruhi pilihan pembelian espresso Arabika di pengecer online, digunakan beberapa survei kejatuhan langsung dengan menggunakan ketentuan sebagai berikut:

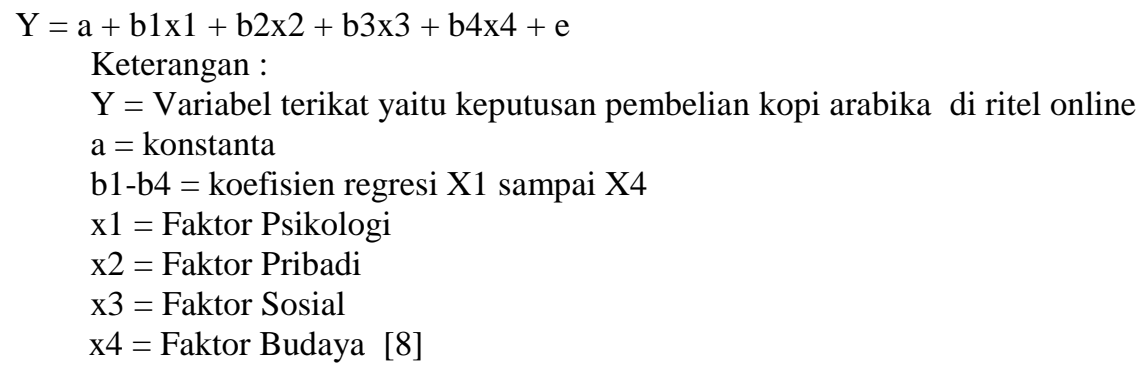

\section{HASIL DAN PEMBAHASAN}

\section{H. Karakteristik konsumen kopi arabika di kabupaten blitar}

Pada tabel 4.1 Karakteristik konsumen kopi arabika di Kabupaten Blitar meliputi usia, jenis kelamin, pendidikan, pekerjaan, pendapatan, jumlah anggota keluarga, waktu konsumsi kopi arabika, frekuensi pembelian kopi arabika, dan rata - rata konsumsi kopi arabika setiap bulannya.

Tabel 1. Distribusi Statistik Karakteristik Responden Penelitian

\begin{tabular}{cccc}
\hline No & Karakteristik Responden & Minimum & Maksimum \\
\hline 1 & Usia & 19 & 45 \\
2 & Jumlah Anggota Keluarga & 2 & $>5$ \\
3 & Rata $-\begin{array}{c}\text { Rata Konsumsi Kopi Arabika } \\
\text { Setiap Bulan }\end{array}$ & 5 & 40 \\
\hline
\end{tabular}

Sumber: Data primer diolah, 2021

Berdasarkan Tabel 1, usia minimum responden adalah 19 tahun dan usia maksimum 45 tahun. Minimum Jumlah anggota keluarga responden adalah sebesar 2 orang dan maksimal sebesar lebih dari 5 orang. Minimum rata - rata konsumsi kopi arabika setiab bulannya yang dilakukan oleh responden adalah sebesar 5 saset dan maksimal sebsesar 40 saset.

Pada tabel 2, menyajikan distribusi frekuensi karakteristik responden penelitian meliputi jenis kelamin, pendidikan, pekerjaan, pendapatan, waktu konsumsi kopi arabika, frekuensi pembelian kopi arabika setiap bulannya. 
Procedia of Engineering and Life Science Vol. 2. No. 1 October 2021

Seminar Nasional \& Call Paper Fakultas Sains dan Teknologi (SENASAINS 3rd)

Universitas Muhammadiyah Sidoarjo

Tabel 2. Distribusi Frekuensi Karakteristik Responden Penelitian

\begin{tabular}{|c|c|c|c|}
\hline No & Karakteristik Responden & Kriteria & Jumlah \\
\hline \multirow{2}{*}{1} & \multirow{2}{*}{ Jenis kelamin } & Laki-laki & 9 \\
\hline & & Perempuan & 21 \\
\hline \multirow{4}{*}{3} & \multirow{4}{*}{ Pendidikan } & SMP & 1 \\
\hline & & SMA & 7 \\
\hline & & $\mathrm{D} 3 / \mathrm{S} 1$ & 22 \\
\hline & & Ibu Rumah Tangga & 3 \\
\hline \multirow{3}{*}{4} & \multirow{3}{*}{ Pekerjaan } & Wiraswasta & 4 \\
\hline & & Mahasiswa & 21 \\
\hline & & Lainnya & 2 \\
\hline \multirow{4}{*}{5} & \multirow{4}{*}{ Pendapatan } & Rp 1.000.000 - Rp 2.000.000 & 9 \\
\hline & & $\operatorname{Rp} 5.000 .00-\operatorname{Rp} 6.000 .000$ & 1 \\
\hline & & $>\operatorname{Rp} 10.000$ & 20 \\
\hline & & Sedang Mulai Mencoba & 9 \\
\hline \multirow{3}{*}{6} & \multirow{3}{*}{ Waktu Konsumsi Kopi Arabika } & 1 Minggu Yang Lalu & 3 \\
\hline & & 1 Bulan Yang Lalu & 2 \\
\hline & & 1 Tahun Yang Lalu & 10 \\
\hline \multirow{6}{*}{7} & \multirow{6}{*}{$\begin{array}{l}\text { Frekuensi Pembelian Kopi } \\
\text { Arabika Setiap Bulan }\end{array}$} & $\begin{array}{l}\text { Lainnya } \\
1 \text { Kali }\end{array}$ & $\begin{array}{c}6 \\
13\end{array}$ \\
\hline & & 2 Kali & 4 \\
\hline & & 3 Kali & 2 \\
\hline & & 4 Kali & 4 \\
\hline & & $>5$ Kali & 3 \\
\hline & & Lainnya & 4 \\
\hline
\end{tabular}

Sumber: Data primer diolah, 2021

Berdasarkan Tabel 2, 30 responden 21 adalah perempuan, sedangkan 9 responden adalah laki-laki. Tingkat pendidikan responden, sebagian besar responden memiliki tingkat lanjut, misalnya 22 responden, 1 responden memiliki pendidikan SLTP dan 7 responden memiliki pendidikan SLTA. Dilihat dari pekerjaan yang diwawancarai, sebagian besar responden adalah pelajar dan pebisnis yang masing-masing terdiri dari 21 responden yang masih pelajar dan 4 responden adalah pebisnis dan 5 responden lainnya mengisi sebagai IRT dan lain-lain.. Berdasarkan Pendapatan responden, sebagian besar responden berpendapatan $>10.000$ hal ini dibuktikan dari data sebanyak 20 responden yang menempati kriteria ini, dan pendapatan responden selanjutnya berkisar antara Rp $1.000 .000-\mathrm{Rp}$ 2.000.000 sebanyak 9 responden, dan 1 orang responden yang berpendapatan sebanyak Rp 5.000.000 - Rp 6.000.000 setiap bulannya.

Jumlah responden dari karakteristik responden berdasarkan waktu konsumsi kopi arabika dapat dijelaskan bahwa sebanyak 10 orang dari keseluruhan jumlah responden yang ditetapkan mengonsumsi kopi arabika sudah dari satu tahun yang lalu, untuk responden yang baru mulai mencoba kopi arabika sebanyak 9 orang, selebihnya jumlah responden yang mengonsumsi kopi arabika dalam waktu satu minggu yang lalu sebanyak 3 orang, dan satu bulan yang lalu sebanyak 2 orang, serta opsi lainnya sebanyak 6 orang dari jumlah responden yang telah ditentukan. Frekuensi pembelian kopi arabika setiap bulannya dominan dilakukan satu kali setiap bulan hal ini dapat dilihat dari data responden yang melakukan pembelian satu kali setiap bulan sebanyak 13 responden, yang melakukan pembelian 2 kali sebulan sebanyak 4 orang responden, tiga kali melakukan pembelian kopi arabika setiap bulan terdapat 2 responden, dan sebanyak 4 responden yang melakukan pembelian kopi arabika 4 kali dalam sebulan dan $>5$ kali melakukan pembelian kopi arabika setiap bulan terdapat 3 responden, dan selebihnya pada opsi lainnya sebesar 4 orang responden yang melakukan pembelian kopi arabika setiap bulannya.

\section{Faktor-faktor yang mempengaruhi konsumen terhadap pembelian kopi arabika secara online}

Variable penelitian yang digunakan untuk membahas faktor-faktor yang mempengaruhi pembelian kopi arabika secara online di Kabupaten Blitar diantaranya adalah $\left(\mathrm{X}_{1}\right)$ Faktor Psikologi, $\left(\mathrm{X}_{2}\right)$ Faktor Pribadi, $\left(\mathrm{X}_{3}\right)$ Faktor Sosial, dan $\left(\mathrm{X}_{4}\right)$ Faktor Budaya. Variable - variabel ini akan diuji dengan analisis regresi linier berganda dengan tujuan untuk 
Procedia of Engineering and Life Science Vol. 2. No. 1 October 2021

Seminar Nasional \& Call Paper Fakultas Sains dan Teknologi (SENASAINS 3rd)

Universitas Muhammadiyah Sidoarjo

membuktikan hipotesis mengenai pengaruh variable - variabel tersebut terhadap pembelian kopi arabika secara online. keputusan pembelian dipengaruhi oleh perilaku konsumen itu sendiri[4]. Dengan dilakukan uji t parsial dan uji $\mathrm{F}$ simultan. Hasil pengolahan data disajikan sebagai berikut :

Hasil uji t parsial

Dengan menggunakan program SPSS selanjutnya hasil uji t parsial dapat diinterpretasikan dan dijelaskan pada tabel berikut ini.

Tabel 3. Hasil Analisis Regresi Linier Berganda

\begin{tabular}{|c|c|c|c|c|c|c|}
\hline \multicolumn{7}{|c|}{ Coefficients $^{\mathrm{a}}$} \\
\hline & & \multicolumn{2}{|c|}{$\begin{array}{l}\text { Unstandardized } \\
\text { Coefficients }\end{array}$} & \multirow{2}{*}{$\begin{array}{l}\text { Standardized } \\
\text { Coefficients }\end{array}$} & & \multirow[b]{2}{*}{ Sig. } \\
\hline \multicolumn{2}{|c|}{ Model } & B & Std. Error & & $\mathrm{T}$ & \\
\hline 1 & (Constant) & -1.084 & 1.280 & & -.847 & .405 \\
\hline & $\begin{array}{l}\text { PSIKOLOGI( } \\
\mathrm{X} 1)\end{array}$ & .180 & .162 & .161 & 1.115 & .276 \\
\hline & PRIBADI(X2) & .157 & .172 & .145 & .911 & .371 \\
\hline & SOSIAL(X3) & 1.012 & .177 & .768 & 5.721 & .000 \\
\hline & BUDAYA(X4) & -.121 & .217 & -.094 & -.557 & .582 \\
\hline & ependent Variab & INDIKA & TOR PEMBE & LIAN & & \\
\hline
\end{tabular}

Sumber : Lampiran output SPSS, 2021

Variabel X3 (sosial) sebesar 0,000, X4 (Pendidikan). Dengan demikian variable sosial sangat berpengaruh terhadap keputusan pembelian kopi arabika di Kabupaten Blitar terlebih secara online.

Model persamaan regresi yang dapat dituliskan dari hasil tersebut dalam bentuk persamaan regresi standardized adalah sebagai berikut:

$\mathrm{Y}=-1,084+0,180 \mathrm{X} 1+0,157 \mathrm{X} 2+1,012 \mathrm{X} 3-0,121 \mathrm{X} 4$

Persamaan regresi tersebut dapat dejelaskan bahwa koefisien regresi variabel psikologi, pribadi, dan sosial sebanyak $0,180,0,157$, dan 1,012. Meningkatnya variabel psikologi, pribadi, dan sosial akan memberikan peningkatan keputusan pembelian. Sedangkan koefisien regresi variabel budaya mempunyai nilai negatif sebesar - 0,121,. Hal ini menunjukkan bahwa peningkatan variabel budaya akan menyebabkan penurunan pada keputusan pembelian.

Uji t variabel psikologi, pribadi, sosial, dan budaya hasil pengujian diperoleh nilai t hitung sebesar $=1,115 ; 0,911$; 5,721; dan -0,557 dengan nilai signifikansi sebesar 0,05. Nilai t tabel dengan $\mathrm{df}=\mathrm{n}-\mathrm{k}-1=30-4-1=25$ maka diperoleh hasil $(\alpha=0,05 ; 25)$ nilai t tabel adalah sebesar 2,059 . Dengan demikian diperoleh thitung $(1,115 ; 0,911$ dan $-0,557)$ $<\mathrm{t}$ tabel $(2,059)$ dan diperoleh nilai signifikansi sebesar $(0,276 ; 0,371$; dan 0,582$)>$ nilai sig. 0,05 yang berarti secara parsial faktor psikologi, faktor pribadi, dan faktor budaya tidak mempengaruhi keputusan konsumen dalam membeli kopi arabika secara online, sehingga dapat dinyatakan hipotesis yang menyatakan bahwa faktor psikologi, faktor pribadi, dan faktor budaya tidak memiliki pengaruh yang signifikan terhadap keputusan pembelian sehingga ditolak.

Sedangkan variable sosial hasil pengujian diperoleh nilai t hitung sebesar 5,721 dengan nilai signifikansi sebesar 0,05 . Nilai $\mathrm{t}$ tabel dengan $\mathrm{df}=\mathrm{n}-\mathrm{k}-1=30-4-1=25$ dengan diperoleh nilai $\mathrm{t}$ tabel sebesar 2,059. Dengan demikian diperoleh $\mathrm{t}$ hitung $(5,721)>\mathrm{t}$ tabel $(2,059)$ dan diperoleh nilai signifikansi sebesar $(0,000)<$ nilai sig. 0,05 yang berarti secara parsial faktor sosial mempengaruhi keputusan konsumen dalam membeli kopi arabika secara online, sehingga dapat dinyatakan hipotesis yang menyatakan bahwa faktor sosial memiliki pengaruh yang signifikan terhadap keputusan pembelian sehingga diterima. 
Procedia of Engineering and Life Science Vol. 2. No. 1 October 2021

Seminar Nasional \& Call Paper Fakultas Sains dan Teknologi (SENASAINS 3rd)

Universitas Muhammadiyah Sidoarjo

Hasil uji fimultan

Tabel 4. Uji F / Simultan

\begin{tabular}{|c|c|c|c|c|c|}
\hline \multicolumn{6}{|c|}{ ANOVA $^{b}$} \\
\hline Model & $\begin{array}{l}\text { Sum of } \\
\text { Squares }\end{array}$ & df & Mean Square & $\mathrm{F}$ & Sig. \\
\hline 1 Regression & 261.964 & 4 & 65.491 & 57.781 & $.000^{\mathrm{a}}$ \\
\hline Residual & 28.336 & 25 & 1.133 & & \\
\hline Total & 290.300 & 29 & & & \\
\hline a. Predictors: & t), BUDAYA( & ), SOSIA & L(X3), PSIKOLC & (X1), PR & $\mathrm{ADI}(\mathrm{X} 2)$ \\
\hline b. Dependent & INDIKATOF & EMBELI & $A N$ & & \\
\hline
\end{tabular}

Sumber : Lampiran output SPSS, 2021

Berdasarkan tabel 4, diketahui nilai signifikansi pengaruh X1, X2, X3, dan X4 secara simultan terhadap Y adalah sebesar $0,000<0,05$ dan nilai $F$ hitung sebesar 57,781 serta $F$ tabel $(\alpha=0,05 ; \mathrm{db}$ regresi $=4 ; \mathrm{db}$ residual $=25)$ adalah sebesar 2,98. Dapat dituliskan F hitung yaitu 57,781 > F tabel yaitu 2,98. Sehingga dapat disimpulkan bahwa hipotesis diterima yang berarti terdapat pengaruh X1, X2, X3, dan X4 secara simultan terhadap Y. Atau dengan kata lain keputusan pembelian kopi arabika secara online dapat dipengaruhi secara simultan oleh faktor psikologi, pribadi, sosial, dan budaya.

\section{KESIMPULAN}

Kualitas pembeli untuk usia 19 - 45, jumlah kerabat 2 -> 5 individu, penggunaan dasar normal espresso Arabika yang dikonsumsi oleh narasumber adalah antara 5 - 40 sachet, 21 adalah wanita dan 9 responden adalah pria, tingkat pendidikan responden, sebagian besar responden memiliki pendidikan lanjutan yaitu 21 orang. Pekerjaan responden sebagian besar adalah substitusi dan sebagian besar responden berpenghasilan lebih rendah > Rp. 10.000 dan ada beberapa responden yang mendapat Rp. 1.000 .000 - Rp. 2.000.000 hingga 9 responden. Ketika mereka melahap espresso Arabika, beberapa telah mencoba baru-baru ini, yang lain telah melakukannya setahun sebelumnya dan peringatan pembelian espresso Arabika setiap bulan adalah bahwa sebagian besar orang yang diwawancarai membeli espresso Arabika sebulan sekali. Faktor - faktor yang mempengaruhi keputusan pembelian kopi Arabika secara online di Kabupaten Blitar menggunakan perhitungan regresi linier berganda didapatkan nilai statistik t hitung variabel psikologi sebesar 1, 115, veariabel pribadi sebesar 0,911, variabel budaya sebesaar 5,721, dan variabel budaya sebesar -0,557. Sedangkan t tabel pada tarf signifikansi 0,05 menunjukan nilai sebesar 2,059. Hal tersebut dapat diartikan bahwa ketiga variabel independen (variabel psikologi, pribadi, dan budaya) tidak berpengaruh signifikan secara parsial terhadap keputusan pembelian kopi arabika secara online kecuali variabel sosial yang berpengaruh signifikan terhadap keputusan pembelian kopi arabika secara online di Kabupaten Blitar karena t hitung $>\mathrm{t}$ tabel. Sedangkan nilai $\mathrm{F}$ hitung sebesar 57,781, dibandingkan $\mathrm{F}$ tabel pada taraf signifikansi 0,05 menunjukan nilai sebesar 2,98. Hal tersebut dapat diartikan bahwa $\mathrm{F}$ hitung $>\mathrm{F}$ tabel sehingga $\mathrm{H}_{0}$ ditolak dan $\mathrm{H}_{1}$ diterima, berarti semua variabel independen secara simultan berpengaruh secara signifikan terhadap keputusan pembelian kopi arabika secara online di Kabupaten Blitar.

\section{REFERENSI}

[1] A. J. N. Dyah, Statistik Deskriptif dan Regresi Linier Berganda Dengan SPSS, Semarang: Semarang University Press, 2012.

[2] R. Anwar \& Adidarma W, "Pengaruh Kepercayaan dan Risiko Pada Minat Beli Belanja Online," Jurnal Manajemen Dan Bisnis Sriwijaya, vol. 14, no. 2, p. 155-168, 2016.

[3] Y. Hendra. N. R, Wirza E \& Irawan M. Z., "Pengaruh Belanja Online Terhadap Perilaku Perjalanan Belanja," Jurnal Transportasi, vol. 15, no. 1, pp. 31-40, 2015.

[4] Phillip Kotler dan Gary Armstrong, Principles of Marketing, Jakarta: Prentice Hall, 2012. 
Procedia of Engineering and Life Science Vol. 2. No. 1 October 2021

Seminar Nasional \& Call Paper Fakultas Sains dan Teknologi (SENASAINS 3rd)

Universitas Muhammadiyah Sidoarjo

[5] Dede Mustomi, Aprilia Puspasari, Ayu Azizah, Diah Wijayanti, "Analisis Belanja Online Di Kalangan Mahasiswa Pada Masa Pandemi Covid 19," Akrab Juara, vol. 5, no. 4, pp. 48-50, 2020.

[6] Henik Prayuningsih, Teguh Hari Santosa, Muhammad Hazmi, Nanang Saiful Rizal, "Peningkatan Daya Saing Kopi Rakyat di Kabupaten Jember," JSEP, vol. 6, no. 3, p. 26, 2012.

[7] Frendy Sondakh \& Perengkuan Tommy, "Current Ratio, Debt To Equity Ratio, Return On Asset, Return On Equity Pengaruhnya Terhadap Harga Saham Pada Indeks LQ 45 Di BEI Periode 2010-2014," Jurnal Emba, vol. 3, no. 2 , pp. 749-756, 2015.

[8] Sugiyono, Statistika Untuk Penelitian, Bandung: CV Alfabeta, 2015.

[9] "International Coffee Organization," 2016. [Online]. Available: https://www.ico.org. [Accessed 26 November 2020].

[10] "Kementrian Pertanian Republik Indonesia," 2016. [Online]. Available: https://www.pertanian.go.id.. [Accessed 18 November 2020]. 